\title{
Biocontrol potential of entomopathogenic nematode species against Tribolium confusum (Jac.) (Coleoptera: Tenebrionidae) and Rhyzopertha dominica (Fab.) (Coleoptera: Bostrichidae) under laboratory conditions
}

\author{
Salma Javed, Tabassum Ara Khanum ${ }^{*}$ and Samreen Khan
}

\begin{abstract}
Grain commodities, like cereals and legumes, are subject to insect infestation during postharvest processing and storage. Public concerns about the potential risks that derive from the consumption of pesticide-treated commodities have created interest for the development and integration in stored product protection of alternative, ecologically safe methods for the disinfestation of stored commodities. The present study was conducted to evaluate the biocontrol potential of four entomopathogenic nematodes (EPNs): Steinernema pakistanense (LM-07), S. bifurcatum (LM-30), S. affinae (GB-14), and S. cholashanense (GB-22) against adult beetles of Tribolium confusum (Jac.) (Coleoptera: Tenebrionidae) and Rhyzopertha dominica (Fab.) (Coleoptera: Bostrichidae) under laboratory conditions. Suspensions of nematodes were applied at three different concentrations, 50, 100, and $150 \mathrm{IJs} / \mathrm{beetle}$ in $1 \mathrm{ml}$ of distilled water at three different temperatures, 20,25 , and $30^{\circ} \mathrm{C}$. Mortality was recorded after 3 days of application. The concentration of $150 \mathrm{IJs} /$ beetle achieved a maximum mortality of $100 \%$ for S. pakistanense at $30^{\circ} \mathrm{C}$. The same concentrations revealed that all four species of EPN were able to cause mortal effects depended on temperature and concentrations. S. pakistanense (LM-07) and S. bifurcatum (LM-30) were the most effective at $150 \mathrm{IJs} /$ beetle at $30^{\circ} \mathrm{C}$ and S. affinae (GB-14) and S. cholashanense (GB-22) at the same concentration at $20^{\circ} \mathrm{C}$.
\end{abstract}

Keywords: Entomopathogenic nematode, Tribolium confusum, Rhyzopertha dominica, Potential, Biocontrol

\section{Background}

Entomopathogenic nematodes (EPNs) such as Steinernema and Heterorhabditis are multicellular organisms that harbor bacteria in their intestine. They have the potential to provide effective control of some economically important insect pests belonging to orders Lepidoptera, Coleoptera, and Diptera (Burnell and Stock 2000). They are established all over the world in diverse ecological habitats and are being developed as one of the biological control agents against insect pests (Cranshaw and

\footnotetext{
* Correspondence: tabassumak@uok.edu.pk

National Nematological Research Centre, University of Karachi, Karachi 75270, Pakistan
}

Zimmerman 2013). In Pakistan, six new EPN species were described: S. pakistanense (Shahina et al. 2001), S. asiaticum (Anis et al. 2002), S. maqbooli (Shahina et al. 2013), S. bifurcatum (Shahina et al. 2014), S. balochiense (Shahina et al. 2015), and Heterorhabditis pakistanense (Shahina et al. 2017), whereas nine species were reported as new records from Pakistan: S. siamkayai (Stock et al. 1998), S. abbasi (Elawad et al. 1997), S.carpocapsae (Wouts et al. 1982), S. feltiae (Filipjev 1934) S. litorale (Yoshida 2004), S. affine (Mracek et al. 2005), S. cholashanense (Nguyen et al. 2008), Heterorhabditis bacteriophora (Poinar Jr 1976), and H. indica (Poinar et al. 1992). 
The lesser grain borer, Rhyzopertha dominica Fabricius (Coleoptera: Bostrichidae), is a destructive, internal grain feeder of stored cereals throughout the world (Mahroof and Phillips 2007). The larvae and adults are more dangerous so that the damage to stored cereal grains is greater than other pests (Vardeman et al. 2007). The confused flour beetle, Tribolium confusum Jacquelin du Val (Coleoptera: Tenebrionidae), is another stored-product pest that contaminates a wide range of food products, from flour and cereals to spices. It effectively exploits food patches of varying sizes and qualities that are produced during various milling operations (Ming and Cheng 2012).

The present study aimed to investigate the biocontrol potential of four Steinernema species against adult beetles of $T$. confusum and $R$. dominica under laboratory conditions.

\section{Materials and methods}

\section{Stock cultures of target pests and entomopathogenic} nematodes

The bulk populations of the stored grain pests, $T$. confusum and $R$. dominica, were obtained from Pakistan Agricultural Research Council (PARC), University of Karachi, Karachi, Pakistan, and further reared in a 1000-ml glass jar at $30 \pm 2{ }^{\circ} \mathrm{C}, 60 \pm 5 \% \mathrm{RH}$, and a photoperiod of $12: 12$ (L:D), covered with the muslin cloths contained fresh whole wheat grain (Triticum aestivum L.) as a diet in a rearing laboratory of National Nematological Research Centre (NNRC), University of Karachi, Karachi, Pakistan. Four species of EPNs, LM-07, LM-30, GB-14, and GB-22, obtained from the stock culture maintained in a storage unit of NNRC, were further propagated in the last instar larvae of Galleria mellonella L. (Pyralidae), following the method of Dutky et al. (1964). The nematodes' infective juveniles (IJs) were harvested from White traps (White 1927) and stored in a $100-\mathrm{ml}$ beaker containing $50 \mathrm{ml}$ distilled water at $10{ }^{\circ} \mathrm{C}$ for 15 days before they were employed for biocontrol potential.

\section{Petri dish bioassay}

Freshly emerged adult beetles of each insect species were collected as a requirement for bioassay from the rearing jars 1 day prior to the application of nematodes. Ten beetles of $T$. confusum and $R$. dominica with 10 fresh grains of wheat (T. aestivum) were placed in Petri dishes $(90 \mathrm{~mm}$ diameter) lined with filter paper disk (Whattmann No. 1) in the bottom of each nematode species, concentrations, and temperatures separately. The biocontrol potential of

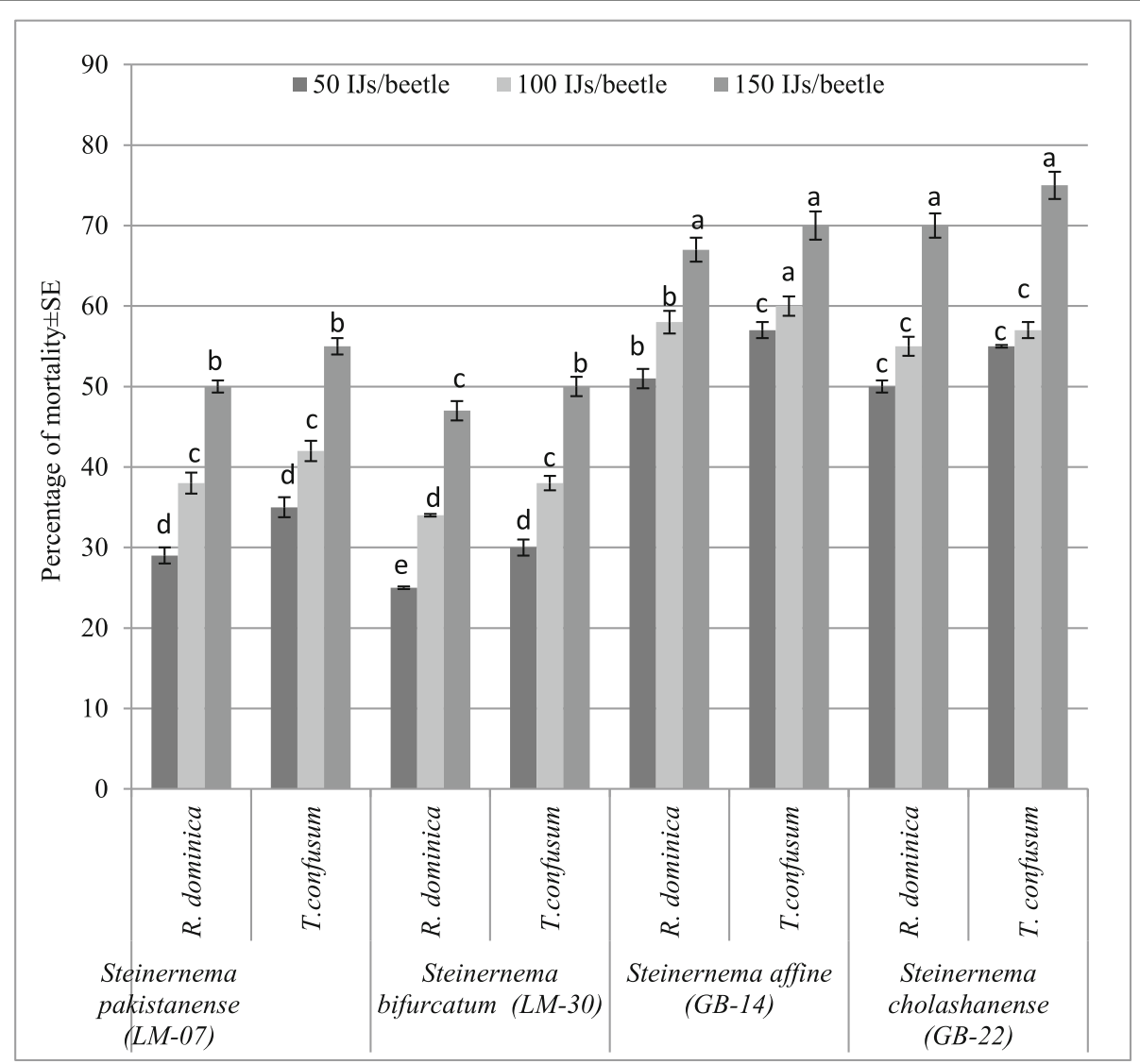

Fig. 1 Adult beetle mean mortality treated with four different species of EPNs in a Petri dish depending on nematode concentrations at $20^{\circ} \mathrm{C}$ 
EPNs was tested at three different concentrations: 50, 100, and $150 \mathrm{IJs} /$ beetle in $1 \mathrm{ml}$ of water. Concentrations were dispensed in a Petri dish with a 100-1000- $\mu$ l micropipette to avoid mixing, Eppendorf tips were replaced after each conduct. For the control treatment, $1 \mathrm{ml}$ distilled water was applied. The Petri dishes were sealed by parafilm (PM-996). Efficacy was tested at three different temperatures $\left(20,25\right.$, and $\left.30^{\circ} \mathrm{C}\right)$. After 3 days, the number of dead beetles was transferred to White trap in a new Petri dish lined with filter paper disk in the bottom to determine the emergence of the nematode under a stereomicroscope. There were four replicates for each treatment combination with concentration, insect, and nematode species, and the entire experiment was carried out twice.

\section{Statistical analysis}

Statistical data were analyzed by multifactor analysis of variance (ANOVA followed by Duncan's multiple range test $(P<0.05)$ for the separation of means (Duncan 1955). $L_{50}$ values were analyzed with probit analysis by using the PROC PROBIT routine of SAS, 2000. Control mortality was corrected as suggested by Abbott (1925).

\section{Results and discussion}

The adult stage of the lesser grain borer and confused flour beetle was found to be susceptible to all the four tested nematode species, but the degree of susceptibility and nematode infection varied according to exposure temperatures and concentrations. The data revealed that at $20^{\circ} \mathrm{C}$, S. affine (GB-14) showed $70,67 \%$ and S. cholashanense (GB-22) 75, and $70 \%$ at 150 IJs/beetle against $T$. confusum and $R$. dominica, respectively, which was the highest mortality effect among other concentrations and nematode species (Fig. 1). At $25^{\circ} \mathrm{C}$, the mortality effect of the targeted pest reduced by these two nematode species (Fig. 2) and increased by S. pakistanense (LM07 ), which caused the highest mortality rate $100,95 \%$ at $100 \mathrm{IJs} /$ beetle at $30^{\circ} \mathrm{C}$, followed by S. bifurcatum (LM30) 80,92 , and $85 \%$ at the concentrations of 50,100 , and 150 IJs/beetle, respectively (Fig. 3). Significant differences in mortality rates were detected between S. pakistanense (LM-07) and S. bifurcatum (LM-30) (ANOVA, $F$ $=4.4 ; \mathrm{df}=7 ; P<0.05)$ at $25^{\circ} \mathrm{C}$, less significant (ANOVA, $F=4.1 ; \mathrm{df}=7 ; P<0.05$ ) at $20^{\circ} \mathrm{C}$, and nonsignificant at $12^{\circ} \mathrm{C}$ (ANOVA, $F=0.48 ; \mathrm{df}=7 ; P<0.8$ ). $S$. cholashanense (GB-22) and S. affine (GB-14) showed a high mortality rate and more significant (ANOVA, $F=$ $4.0 ; \mathrm{df}=7 ; P<0.05)$ at $20^{\circ} \mathrm{C}$, whereas non-significant (ANOVA, $F=0.76$; $\mathrm{df}=7 ; P<0.62$ ) at $30^{\circ} \mathrm{C}$. The nematode concentrations $(50,100$, and $150 \mathrm{IJs} / \mathrm{ml})$ also differed significantly (ANOVA, $F=4.2 ; \mathrm{df}=3 ; P<0.05$ ). $R$. dominica was highly susceptible against $S$. pakistanense

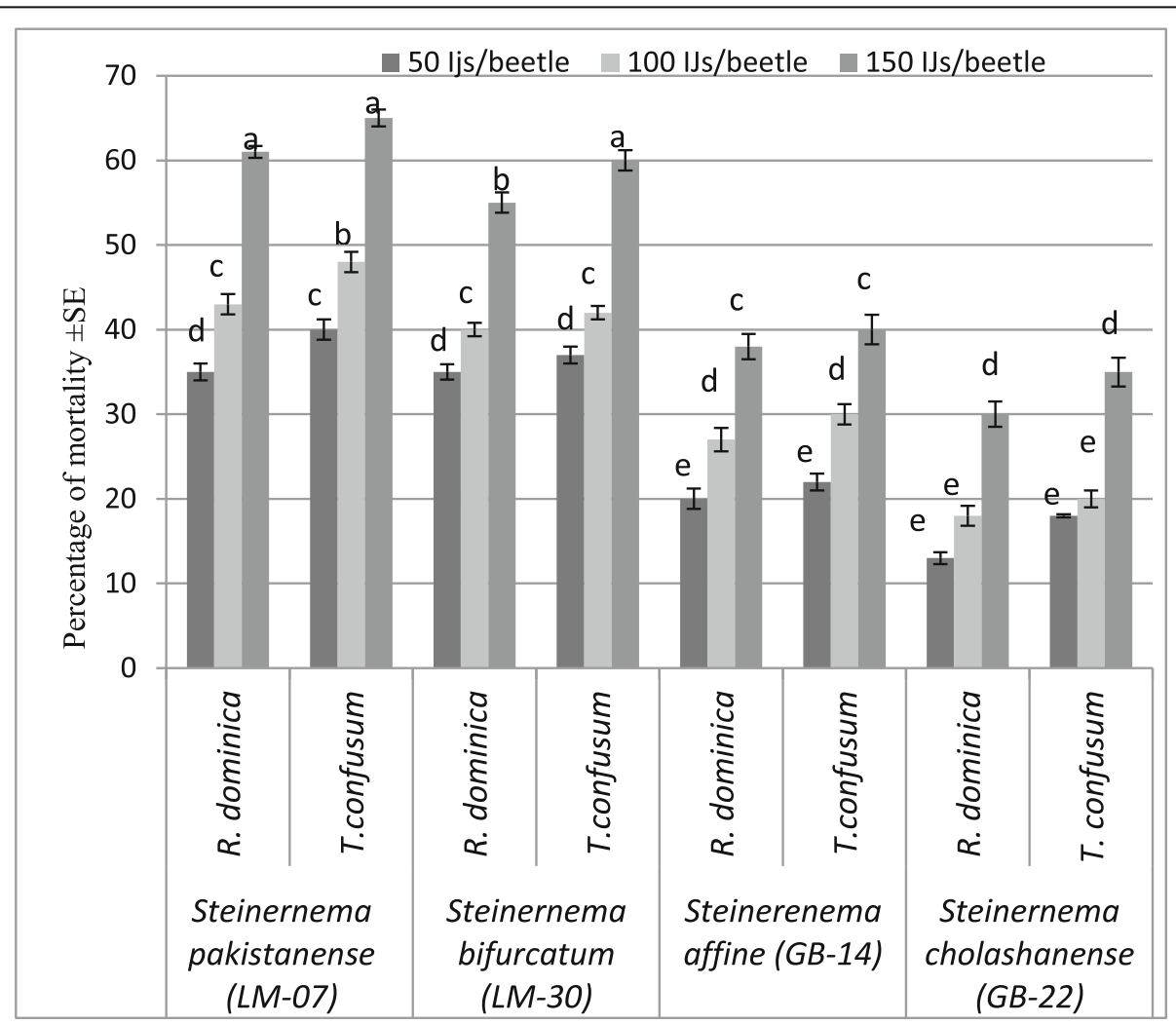

Fig. 2 Adult beetle mean mortality treated with four different species of EPNs in a Petri dish depending on nematode concentrations at $25^{\circ} \mathrm{C}$. 


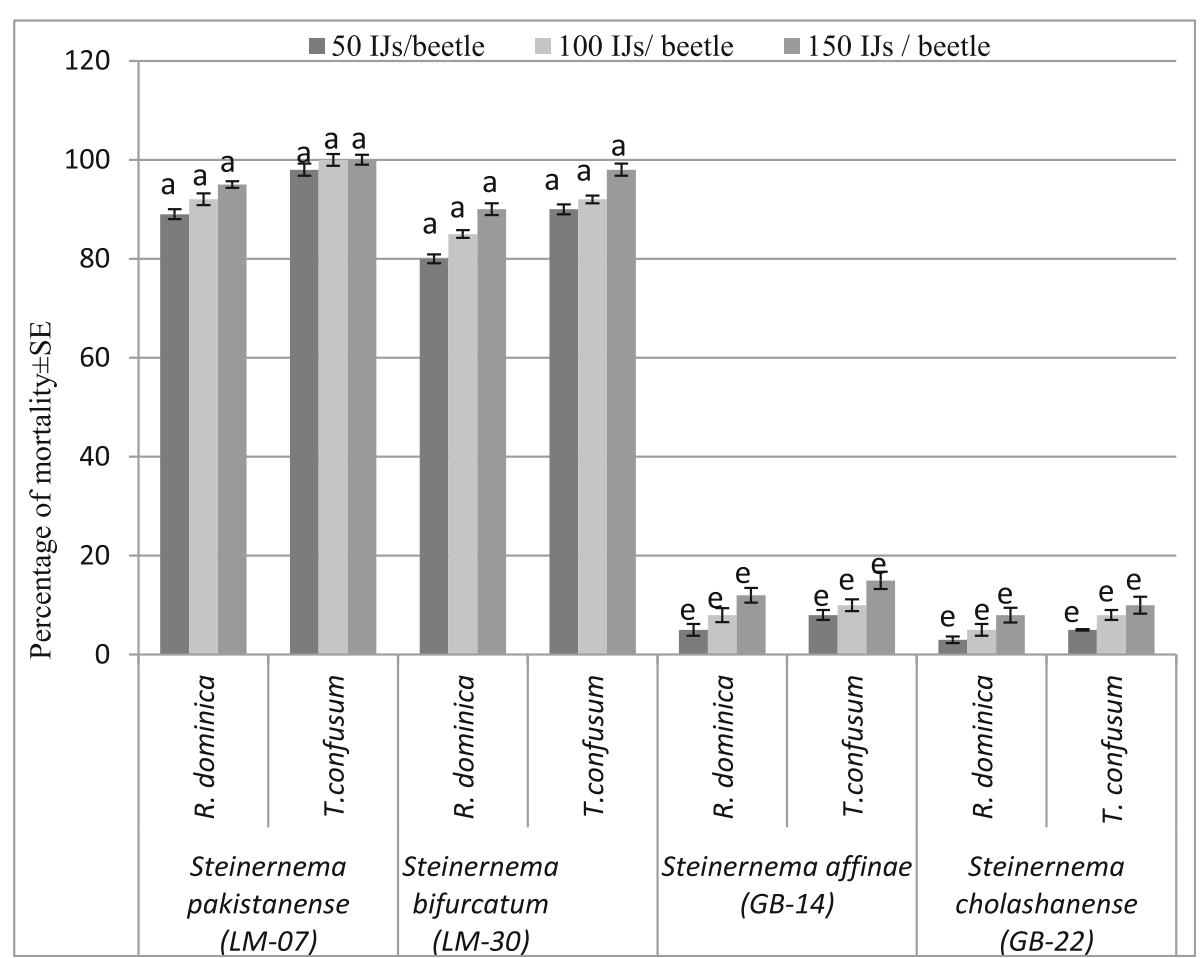

Fig. 3 Adult beetle mean mortality treated with four different species of EPNs in aPetri dish depending on nematode concentrations at $30^{\circ} \mathrm{C}$

(LM-07) and $S$. bifurcatum (LM-30) (ANOVA, $F=5$, 25; df $=3 ; P<0.05)$ at $25^{\circ} \mathrm{C}$, whereas in the case of $20^{\circ} \mathrm{C}, R$. dominica was highly susceptible against $S$. cholashanense (GB-22) and $S$. affine (GB-14) (ANOVA, $F=5.14$; df = 3 ; $P<0.05)$. T. confusum was highly susceptible against S. pakistanense (LM-07) and S. bifurcatum (LM-30) (ANOVA, $F=5.25$; $\mathrm{df}=3 ; P<0.05$ ) at 25 and $30^{\circ} \mathrm{C}$, whereas in the case of $20^{\circ} \mathrm{C}$, it was highly susceptible against $S$. cholashanense (GB-22) and S. affine (GB-14) (ANOVA, $F=0.8 ; \mathrm{df}=3 ; P<0.05$ ). S. pakistanense (LM-07) showed non-significant differences in mortality rates of both insects at $20^{\circ} \mathrm{C}$ (ANOVA, $F=0.48$; df $=7$;
$P<0.05)$, whereas a more significant difference at $30{ }^{\circ} \mathrm{C}$ (ANOVA, $F=14$; df $=5 ; P<0.05$ ). S. bifurcatum (LM30) showed a high mortality rate and the most significant (ANOVA, $F=22 ; \mathrm{df}=5 ; P<0.05$ ) at $30^{\circ} \mathrm{C}$, while non-significant at $20^{\circ} \mathrm{C}$ (ANOVA, $F=14$; df $=1 ; P<$ 0.05). S. cholashanense (GB-22) showed significant differences in mortality rates of both insects at $20^{\circ} \mathrm{C}$ (ANOVA, $F=31.6 ; \mathrm{df}=5 ; P<0.05$ ), while nonsignificant at $30^{\circ} \mathrm{C}$ (ANOVA, $F=0.8 ; \mathrm{df}=1 ; P<0.05$ ). $S$. affine (GB-14) showed a high mortality rate and more significant (ANOVA, $F=14 ; \mathrm{df}=3 ; P<0.05$ ) at $20^{\circ} \mathrm{C}$, whereas non-significant at $30^{\circ} \mathrm{C}$ (ANOVA, $F=1.2 ; \mathrm{df}=$

Table 1 Median lethal concentrations $\left(\mathrm{LC}_{50}\right)$ of four nematode species against adult stages of Rhyzopertha dominica and Tribolium confusum

\begin{tabular}{|c|c|c|c|c|c|c|}
\hline \multirow[t]{3}{*}{ EPN species } & \multicolumn{6}{|l|}{$\mathrm{LC}_{50}(95 \% \mathrm{CL})$} \\
\hline & \multicolumn{2}{|l|}{$20^{\circ} \mathrm{C}$} & \multicolumn{2}{|l|}{$25^{\circ} \mathrm{C}$} & \multicolumn{2}{|l|}{$30^{\circ} \mathrm{C}$} \\
\hline & T. confusum & R. dominica & T. confusum & R. dominica & T. confusum & R. dominica \\
\hline $\begin{array}{l}\text { Steinernema pakistanense } \\
\text { LM-07 }\end{array}$ & $\begin{array}{l}128.46(357.5- \\
93.07)\end{array}$ & $\begin{array}{l}166.9(372.1- \\
124.72)\end{array}$ & $86.71(117.0-61.2)$ & $\begin{array}{l}208.7(259.10- \\
158.4)\end{array}$ & $\begin{array}{l}1.671(251.61- \\
0.011)\end{array}$ & $\begin{array}{l}1.671(251.61- \\
0.011)\end{array}$ \\
\hline $\begin{array}{l}\text { Steinernema bifurcatum LM- } \\
30\end{array}$ & $\begin{array}{l}137.6(262.4- \\
105.5)\end{array}$ & $\begin{array}{l}164.40(209.53- \\
119.2)\end{array}$ & $\begin{array}{l}109.88(190.4- \\
81.5)\end{array}$ & $\begin{array}{l}133.33(186.28- \\
80.38)\end{array}$ & $5.1193(19.52-0)$ & $\begin{array}{l}5.676(89.72- \\
0.359)\end{array}$ \\
\hline Steinernema affine GB-14 & $\begin{array}{l}30.55(109.8- \\
8.49)\end{array}$ & $\begin{array}{l}49.284(75.39- \\
0.68)\end{array}$ & $\begin{array}{l}276.55(251.5- \\
147.14)\end{array}$ & $\begin{array}{l}199.35(251.55- \\
147.14)\end{array}$ & $\begin{array}{l}429.42(501.46- \\
357.3)\end{array}$ & $\begin{array}{l}723.73(915.2- \\
532.1)\end{array}$ \\
\hline $\begin{array}{l}\text { Steinernema cholashanense } \\
\text { GB-22 }\end{array}$ & $\begin{array}{l}39.267(66.638- \\
0)\end{array}$ & $\begin{array}{l}55.756(78.47- \\
14.04)\end{array}$ & $\begin{array}{l}230.62(20.47- \\
180.77)\end{array}$ & $\begin{array}{l}441.99(283.78- \\
195.24)\end{array}$ & $\begin{array}{l}506.94(601.15- \\
412.74)\end{array}$ & $\begin{array}{l}445.15(545.85- \\
344.4)\end{array}$ \\
\hline
\end{tabular}

$\mathrm{LC}_{50}$ expressed as no. of IJs per beetle

Confidence limit, $\mathrm{CL}$, are given in parenthesis 
1; $P<0.05)$. $\mathrm{LC}_{50}$ values calculated from probit analysis of all tested nematode strains are given in Table $1 . S$. pakistanense (LM-07) and S. bifurcatum (LM-30) were the most effective at high temperatures, whereas $S$. affine (GB-14) and S. cholashanense (GB-22) were the lowest one.

Research studies on the efficacy of EPNs against stored-product insects are restricted, and the research conducted in laboratory conditions so far provides strong evidence that EPNs are a promising tool for the control of postharvest insects. Early studies evaluated the virulence of Steinernema feltiae Filipjev (formerly Neoplectana carpocapsae) (Alikhan et al. 1985) and S. carpocapsae Weiser (Wójcik 1986) against adults of $S$. granaries. Various studies have also been conducted for the evaluation of the virulence of EPNs against the stored grain pest $T$. castaneum (Ramos-Rodríguez et al. 2006) and the confused flour beetle, Tribolium confusum (Alikhan et al. 1985; Athanassiou and Kavallieratos 2010; Rumbos and Athanassiou 2012). Larvae of T. castaneum were highly susceptible to three steinernematid species, i.e., S. feltiae, S. carpocapsae, and S. riobrave, whereas for pupae and adults, susceptibility was speciesdependent (Ramos-Rodríguez et al. 2006). Six heattolerant Pakistani nematode strains also showed successful results against $T$. castaneum larvae and adults (Shahina and Salma 2010; 2011). For T. confusum larvae, different responses to EPNs have been demonstrated, varying from low (Alikhan et al. 1985; Rumbos and Athanassiou 2012) to high susceptibility (Athanassiou et al. 2008), depending mainly on the nematode species and strain. However, most studies agree on the poor infectivity of EPNs against $T$. confusum adults (Athanassiou et al. 2008; Rumbos and Athanassiou 2012). R. dominica larvae develop inside the kernel; hence, studies with EPNs have focused on the susceptibility of the freeliving adult stage, which exhibited low to moderate susceptibility (Ramos-Rodríguez et al. 2006; Athanassiou and Kavallieratos 2010). Trdan et al. (2006) also studied the effect of two heterorhabditid species, Heterorhabditis bacteriophora Poinar and H. megidis Poinar, Jackson and Klein, with $H$. megidis being the least efficient. Laznik et al. (2010) noted high mortalities at the highest nematode suspension concentration (2000 IJs/insect) of three S. feltiae strains, whereas Shahina and Salma (2010) reported an increased susceptibility of the rice weevil Sitophilus oryzae adults to six Pakistani EPN strains. These contradicting results indicate that the various nematode and host strains used, as well as the different experimental protocols followed, may have an impact on the results. Low susceptibility to EPNs was shown also for the maize weevil S. zeamais (Barbosa-Negrisoli et al. 2013).

Therefore, there is a substantial gap in field studies, where the efficacy of the large-scale application of EPNs will be evaluated under "real world" conditions. The low humidity conditions that prevail in these facilities, especially in warm regions, could affect the survival and virulence of EPNs negatively and subsequently reduce their efficacy. To overcome these limitations, the development of EPN formulations and evaluation of heat-tolerant strains of EPNs needs further investigation.

\section{Conclusion}

The evaluation of EPNs against stored-product insects, providing evidence that EPNs can provide adequate control of postharvest insects but at certain conditions, could be included in future pest management strategies in storage facilities.

\section{Acknowledgements \\ Not applicable}

\section{Authors' contributions}

SJ designed the study, wrote the manuscript, and inputted from all authors. TAK analyzed the data and SK carried out the experiment. All authors read and approved the final manuscript.

\section{Funding}

No funding

Availability of data and materials

All data and materials are mentioned in the manuscript.

Ethics approval and consent to participate

Not applicable

Consent for publication

Not applicable

\section{Competing interests}

The authors declare that they have no competing interests.

Received: 7 November 2019 Accepted: 13 January 2020

Published online: 21 January 2020

References

Abbott WS (1925) A method of computing the effectiveness of insecticide. J Econ Entomol 18:265-267

Alikhan MA, Bednarek A, Grabiec S (1985) The physiological and morphological characteristics of Neoaplectana carpocapsae (Nematoda: Steinernematidae) in two insect hosts. J Invertebr Pathol 45:168-173

Anis M, Shahina F, Reid AP, Rowe J (2002) Steinernema asiaticum sp. $n$. (Rhabditida: Steinernematidae) from Pakistan. Int J Nematol 12:220-231

Athanassiou, CG, Kavallieratos, NC Menti, H Karanastasi E (2010) Mortality of four stored product pests in stored wheat when exposed to doses of three entomopathogenic nematodes. J Econ Entomol, 103: 977-984

Athanassiou CG, Palyvos NE, Kakouli-Duarte T (2008) Insecticidal effect of Steinernema feltiae (Filipjev) (Nematoda: Steinernematidae) against Tribolium confusum du Val (Coleoptera: Tenebrionidae) and Ephestia kuehniella (Zeller) (Lepidoptera: Pyralidae) in stored wheat. J Stored Prod Res 44:52-57

Barbosa-Negrisoli CRDC, Negrisoli ASJ, Bernardi D, Garcia MS (2013) Activity of eight strains of entomopathogenic nematodes (Rhabditida:

Steinernematidae, Heterorhabditidae) against five stored product pests. Exp Parasitol 134:384-388

Burnell AM, Stock SP (2000) Heterorhabditis, Steinernema and their bacterial symbionts - lethal pathogen of insects. Nematology 2:31-42

Cranshaw WS Zimmerman R (2013) Insect Parasitic Nematodes. Fact Sheet No 5. 573. Colorado State University Extension. Available at: http://extension. colostate.edu/docs/pubs/insect/05573.pdf (accessed 19 Sept 2016)

Duncan DB (1955) Multiple range and multiple F-test. Biometrics 11:1-14 
Dutky SR, Thompson JV, Cantwell GE (1964) A technique for the mass production of the DD-136 nematode. J. Insect Pathology 6:417-422

Elawad AS, Ahmad W, Reid AP (1997) Steinernema abbasi sp. n. (Nematoda: Steinernematidae) from the Sultanate of Oman. Fundam Appl Nematol 20: 435-442

Filipjev IN (1934) Miscellanea Nematologica. 1. Eine neue Art der Gattung Neoplectana Steiner nebst Bemerkunge über die systematische stellung der letzeren. Magazine de Parasitologie de I'Institute Zoologique de l'Academie de I'USSR 4:229-240

Laznik Z, Tóth T, Lakatos T, Vidrih M, Trdan S (2010) The activity of three new strains of Steinernema feltiae against adults of Sitophilus oryzae under laboratory conditions. J Food Agric and Environ 8:150-154

Mahroof RM, Phillips TW (2007) Stable isotopes as markers to investigate host use by Rhyzopertha dominica (F.) (Coleoptera: Bostrichidae). Entomol Exp Appl 125:205-213

Ming QL, Cheng C (2012) Influence of nutrition on male development and reproduction in Tribolium castaneum. J Econ Entomol 105:1471-1476

Mracek Z, Kindlmann P, Webster JM (2005) Steinernema affine (Nematoda: Steinernematidae), a new record for North America and its distribution relative to other entomopathogenic nematodes in British Columbia. Nematol. 7:495-501

Nguyen KB, Puza V, Mracek Z (2008) Steinernema cholashanense n. sp. (Rhabditida: Steinernematidae) a new species of entomopathogenic nematode from the province of Sichuan, Chola Shan Mountains, China. J Invertebr Pathol 97:251-264

Poinar GO, Karunakar GK, David H (1992) Heterorhabditis indicus n. sp. (Rhabditida: Nematoda) from India: separation of Heterorhabditis spp. by infective juveniles. Fundam Appl Nematol 15:467-472

Poinar GO Jr (1976) Description and biology of a new insect parasitic rhabditoid, Heterorhadbitis bacteriophora n. gen., n. sp. (Rhabdtoida; Heterorhabditidae n. fam.). Nematologica 21:463-470

Ramos-Rodríguez O, Campbell JF, Ramaswamy SB (2006) Pathogenicity of three species of entomopathogenic nematodes to some major storedproduct insect pests. J Stored Prod Res 42:241-252

Rumbos Cl, Athanassiou CG (2012) Insecticidal effect of six entomopathogenic nematode strains against Lasioderma serricorne (F.) (Coleoptera: Anobiidae) and Tribolium confusum Jacquelin du Val (Coleoptera: Tenebrionidae). J Stored Prod Res 50:21-26

Shahina F, Anis M, Reid AP, Rowe J, Maqbool MA (2001) Steinernema pakistanense sp. n. (Rhabditida: Steinernematidae) from Pakistan. Int. J Nematol 11:124133

Shahina F, Salma J (2010) Laboratory evaluation of seven Pakistani strains of entomopathogenic nematode against a stored product insect pest, rice weevil (Sitophilus oryzae L.). Pak J Nematol 28:295-305

Shahina F, Salma J (2011) Pakistani strains of entomopathogenic nematode as a biological control agent against stored grain pest, Tribolium castaneum. Pak $J$ Nematol 29:25-34

Shahina F, Tabassum KA, Ali S, Solangi GS, Mehreen G, Salma J (2015) Steinernema balochiense n. sp. (Rhabditida: Steinernematidae) a new entomopathogenic nematode Pakistan. Zootaxa 3904:387-402

Shahina F, Tabassum KA, Mehreen G, Salma J (2013) Steinernema magbooli n. sp. (Rhabditida: Steinernematidae) a species of the 'bicornutum' group from Pakistan. Int. J Nematol 23:59-72

Shahina F, Tabassum KA, Salma J, Mehreen G, Knoetze R (2017) Heterorhabditis pakistanense n. sp. (Nematoda: Heterorhabditidae) a new entomopathogenic nematode Pakistan. J Helminthol 91:222-235

Shahina F, Xun Y, Lihong Q, Richou H, Mehreen G, Tabassum AK, Salma J (2014) A new entomopathogenic nematode, Steinernema bifurcatum n. sp. (Rhabditida: Steinernematidae) from Punjab, Pakistan. Nematol 16:821-836

Stock SP, Somsook V, Reid AP (1998) Steinernema siamkayai n. sp. (Rhabditida: Steinernematidae) an entomopathogenic nematode from Thailand. Syst Parasitol 41:105-113

Trdan S, Vidric M, Valic N (2006) Activity of four entomopathogenic nematodes against young adult of Sitophilus granarious (Coleoptera: Curculionidae) and Oryzaephilus surinomensis (Coleoptera: Silvanidae) under laboratory condition. Plant, Dis Prot 113:168-173

Vardeman, EA, Arthur, FH. Nechols, JR. Campbell JF (2007). Efficacy of surface applications with diatomaceous earth to control Rhyzopertha dominica (F.) (Coleoptera, Bostrichidae) in stored wheat. J Stored Prod Res., 43: 335-341

White GF (1927) A method for obtaining infective nematode larvae from cultures. Science 66:302-303
Wójcik WF (1986) Influence of the size of host on the growth of the Neoplectana carpocapsae Weiser, 1955 nematodes. Annals of Warsaw Agricultural University SGGW-AR Animal. Science 20:75-85

Wouts WM, Mracek Z, Gerdin S, Bedding RA (1982) Neoplectana Steiner, 1929 a junior synonym of Steinernema Travassos, 1927 (Nematoda: Rhabditida). Parasitol. 4:147-154

Yoshida M (2004) Steinernema litorale n. sp. (Rhabditida: Steinernematidae), a new entomopathogenic nematode from Japan. Nematol. 6:819-838

\section{Publisher's Note}

Springer Nature remains neutral with regard to jurisdictional claims in published maps and institutional affiliations.

\section{Submit your manuscript to a SpringerOpen ${ }^{\circ}$ journal and benefit from:}

- Convenient online submission

- Rigorous peer review

- Open access: articles freely available online

High visibility within the field

- Retaining the copyright to your article

Submit your next manuscript at $>$ springeropen.com 